\title{
An Empirical Analysis of the Effects of Population Growth on Economic Growth in Ethiopia using an Auto Regressive Distributive Lag (ARDL) Model Approach
}

\author{
Alemayehu Temesgen Befikadu ( $\nabla$ alextame9@gmail.com ) \\ Ambo University College of Business and Economics https://orcid.org/0000-0002-7541-1272 \\ Berhanu Alemu Tafa \\ Ambo University College of Business and Economics
}

\section{Research note}

Keywords: ARDL, Economic growth, Population growth

Posted Date: June 25th, 2021

DOl: https://doi.org/10.21203/rs.3.rs-646003/v1

License: (c) (i) This work is licensed under a Creative Commons Attribution 4.0 International License.

Read Full License 
An Empirical Analysis of the Effects of Population Growth on Economic Growth in Ethiopia using an Auto Regressive Distributive Lag (ARDL) Model Approach

\section{Set By: -}

1. Name: Alemayehu Temesgen Befikadu (MSc) : Corresponding Author alextame9@gmail.com,

Department of Economics, Ambo University, Ambo, Ethiopia

Tell: +251911534723

2. Berhanu Alemu Tafa (Assistance Professor, PHD) berhanuje@gmail.com,

Department of Economics, Ambo University

Ambo, Ethiopia

Tell: +251913652478 



\begin{abstract}
Objective

The study examines An Empirical Analysis of the Effects of Population Growth on Economic Growth in Ethiopia using an Auto Regressive Distributive Lag (ARDL) Model Approach from the period of 1980 through 2019 with specific focus on total population, Growth Domestic Product, population growth rate, and foreign direct investment, inflow. This study investigated to understand the effects of total population on economic growth, and to analyze the short run and long run relationship of economic growth with respect to population growth.

Results

From the results of the study, personal remittance is stationary at level, while total population, FDI net inflows, population growth rate, rate of inflation, and gross capital formation are stationary at first difference. From the finding of long run equilibrium relationships between RGDP, population number, FDI, personal remittance, population growth rate, rate of inflation and GCF is existed since the value of F-statics is greater than the upper boundary line. Finally, to increase the economic growth of Ethiopia; the government should adopt policies that can attract the foreign investors. The government also should put a standard to guarantee that the economy grows at a larger rate than the population growth.
\end{abstract}

Key words: ARDL, Economic growth, Population growth 


\section{Introduction}

As the twenty first century started, the world's population was calculated to be almost six point one billion people. Projections by the United Nations placed the figure more than nine point two billion by the year of 2050 before attempting a maximum of 11 billion by 2200 . Over $90 \%$ of that population will occupy the developing world (Todaro and Smith, 2006).

According to Anulawathie Menike (2018), there exists a close and reciprocal relationship between population growth and economic development in a country. The population in one way constitutes a source of labor that could be utilized to boost the country's production.

Ethiopia's population is increasing in an amazing rate. Around $20^{\text {th }}$ century, the number of Ethiopian populations believed to be 11.75 million with $0.2 \%$ annual growth rate and it assumed to be doubled in 346 years. However, the number of populations of Ethiopia was doubled within 60 years. From the reports of population census of 1984, 1994 and 2007; the population of Ethiopia was 39.37 million, 55.18million and 80.67 million, respectively. Therefore, in order to double the population growth from census report of 2007 it only needs 27 years.

According to Felmingham (2004), "a large population growth on the other side is not only associated with food problem but also imposes constraints on the development of savings, foreign exchange and human resources".

The trends suggest that the interaction of population pressures and the economy is a very important issue and may have contributed to perpetuation of poverty trap in Ethiopia. Specifically, this study tries to know the effects of total population on economic growth analyze the short run and long run relationship of economic growth.

\section{Mani Text}

\subsection{METHODOLOGY}

\subsubsection{Data Type and Source}

In this study, secondary data were used to analyze the relationship between variables. The time series data of Ethiopia from World Bank database from 1980 to 2019 were used.

\subsubsection{The Autoregressive Distributed Lag (ARDL) Model}

ARDL model is used in order to undertake this study. The resercher applied ARDL model because it allows capturing sufficient number of lags in data generating process. ARDL 
technique applied irrespective of whether the underlying variables are $\mathrm{I}(0)$ or $\mathrm{I}(1)$ or a combination of both but not I (2). The major advantage of this approach was laid in its identification of the co-integrating vectors where there are multiple co-integrating vectors.

\subsubsection{Lag Selection Criteria}

The issue of finding the appropriate lag length for each of the underlying variables in the ARDL model was very important. Because: we were needed to have Gaussian error terms (i.e. standard normal error terms that do not suffer from non normality, autocorrelation, etc). In order to select the appropriate number of lags for the long run underlying equation, the researcher determined the optimal lag length (k) by using the lower values of Akaike Information Criteria (AIC), Schwarz Bayesian Criteria (SBC) or Hannan-Quinn Criteria (HQC) (Nkoro \& Kelvin, 2016).

We specify those common information criteria as follows:

$$
\begin{aligned}
& \operatorname{AIC}(m)=\log \left|\widehat{\Sigma}_{m}\right|+\frac{2}{T} m k^{2} \\
& S C(m)=\log \left|\widehat{\Sigma}_{m}\right|+\frac{\log T}{T} m k^{2} \\
& \operatorname{HQC}(m)=-2 \log \left|\widehat{\Sigma}_{m}\right|+2 k \log (\log (T)
\end{aligned}
$$

Where $\sum_{m}$ is likelihood value, $\mathrm{T}$ is number of observation, while $m$ is the order and $k$ is number of variables.

Given a set of candidate values for the data, the preferred value is the one with the minimum the value of AIC, SC and HQC always suggests the best lag length to be chooses in each model.

\subsubsection{The Long Run ARDL Model}

To examine the existence of the long run relationship between the variables the following version of ARDL model was used.

$$
\begin{aligned}
& \ln G R G D P t=\alpha_{0}+\sum_{j=1}^{q} \beta_{J} \ln R G D P_{t-i}+\sum_{i=1}^{p} \gamma_{i} \operatorname{lnPOP}_{t-i}+\sum_{i=1}^{p} \theta_{i} \operatorname{lnFDI}_{t-i}+\sum_{i=1}^{p} \delta_{i} \ln F R E M_{t-i}+\sum_{i=1}^{p} \vartheta_{i} \ln P O G R_{t-i} \\
& +\sum_{i=1}^{p} \varphi_{i} \operatorname{lnRI_{t-i}}+\sum_{i=1}^{p} \Gamma_{i} \ln G C F_{t-i}+\varepsilon_{t}-----(4)
\end{aligned}
$$

\subsubsection{Short Run and the Error Correction Model (ECM)}

Once the long run model was estimated, the next task was to model the short run dynamics of the model by estimating an Error Correction Model associated with the long run estimates. This was specified as follows:- 


$$
\begin{aligned}
\Delta \ln G R G D P t= & \beta_{0}+\sum_{i=1}^{p} \beta_{1 i} \Delta \ln G R G D P t_{t-i}+\sum_{i=1}^{k} \beta_{2 i} \Delta \operatorname{lnPOP} t-i+\sum_{i=1}^{k} \beta_{3 i} \Delta \operatorname{lnFDI} I_{t-i} \\
& +\sum_{i=1}^{k} \beta_{4 i} \Delta \operatorname{lnPREM}_{t-i}+\sum_{i=1}^{k} \beta_{5 i} \Delta \operatorname{lnPOPG}_{t-i}+\sum_{i=1}^{k} \beta_{6 i} \Delta \ln R I_{t-i}+\sum_{i=1}^{k} \beta_{7 i} \Delta L N G C F_{t-\mathrm{i}} \\
& +\alpha E C T_{t-1}+\varepsilon_{t}------------(5)
\end{aligned}
$$

$E C M_{t-1}$ is the error correction term that will be obtained from ARDL long run dynamics of the model and it is expected to have negative sign. It indicates the speed of adjustment back to longrun equilibrium after a short-run shock.

\subsubsection{Stability test}

Pesaran and Pesaran (1997) suggest using Brown et al. (1975) stability test which was known as cumulative sum of squares test (CUSUMSQ).

\subsection{Results and Discussions}

\subsubsection{Descriptive Analysis}

We observed that; Real Gross Domestic product and number of population have different rate of growth. Specifically, the number of population has almost the same rate while the rate of Real GDP increases with constant phase and dramatically changes.

In 1980, the numbers of population in Ethiopia were around 35 million people and 9 years later in 1988 the number of population were increased to 45 million people. Then, the number of population was reached 55 million within 6 years in 1994; consequently, in 2002 the number of population increased to $70,142,091$.

\subsubsection{Results of Lag selection criteria}

The guideline for selecting the lag selection criteria depends on the lower value of AIC (Akaike Information Criteria), SC (Schwarz information Criteria) and HQ (Hannan-Quinn information Criteria). Thus, the optimal lags are selected based on minimum value of AIC, SC and HQ. From the entire top 20 model; ARDL $(2,0,1,1,0,3,3)$ have lower values of the three (AIC, SC and HQ) information criteria.

\subsubsection{ARDL Long Run}

After checking the existence of long run relationships, the next step is estimation of the long run coefficients. In most of regression analysis, researchers have been predicting the values of 
the unknown dependent variables based on the known values of the independent variables. The result of the best-fitted ARDL model by information criteria is given in table below.

\section{Table 1: Results of ARDL coefficient of long run}

\begin{tabular}{crrrr}
\hline \hline Variable & Coefficient & Std. Error & t-Statistic & Prob. \\
\hline \hline LNPOP & 0.390532 & 0.078782 & 4.957101 & 0.0001 \\
lnFDI & $1.30 \mathrm{E}-10$ & $2.18 \mathrm{E}-11$ & 5.992954 & 0.0000 \\
lnPREM & 0.000167 & $6.59 \mathrm{E}-05$ & 2.529943 & 0.0204 \\
LNPOPGR & -0.137015 & 0.171129 & -0.800652 & 0.4332 \\
lnRI & -0.011479 & 0.001740 & -6.598554 & 0.0000 \\
LNGCF & 0.495917 & 0.050657 & 9.789717 & 0.0000 \\
C & 2.100256 & 1.127419 & 0.088925 & 0.9301 \\
\hline \hline
\end{tabular}

Source: Authors own computation from ARDL long run

From table 1, except population growth rate, all variables are statistically significant since the p-value is less than $5 \%$ level of significance.

From table 1, the researcher developed the long run ARDL model equation as follows:

$$
\begin{aligned}
\mathrm{LNRGDP}= & 2.1003+0.390532 \mathrm{LNPOP}+1.30 \mathrm{e}^{-10} \text { FDI }+0.000167 \text { PREM }-0.137015 \\
& \text { LNPOPGR }-0.011479 \mathrm{RI}+0.495917 \mathrm{LNGCF}
\end{aligned}
$$

The number of population (POP), which is the main variable for this study, was found to have a positive and statistically significant at $1 \%$ significant level in explaining economic growth. As it expected; population size has a positive effect on economic growth of Ethiopia. From the result of long run ARDL model, population size is statistically significant at $1 \%$ level having probability values of $0.01 \%$. We can interpret it, as a one percent increase in population number will result an increase in economic growth by 39.05 percent.

Inflation rate has a negative coefficient. It affects economic growth negatively because its probability value is less than 5\% level. Rate of Inflation has a p-value of $0 \%$ : which is less than $5 \%$ level and it was statistically significant. Thus, a $1 \%$ increase in inflation rate will results in a decrease of economic growth by $1.1479 \%$.

However, Population Growth Rate (POPGR) is not statistically significant having probability values of $43.32 \%$. Population growth rate is not significant having p-values of greater than $5 \%$.

\subsubsection{Results of Short Run and Error Correction Model}

The next step was estimation of the short run coefficients with the short run Error Correction Term (ECT). Since, the long run model is clearly specified and the effect of the regressors on 
the regress and is clearly interpreted. Thus, the ECT shows the short run dynamics of the model be side with the long run adjustment.

\section{Table 2: Results of short run ARDL and Error Correction model}

\begin{tabular}{crrrr}
\hline \hline Variable & Coefficient & Std. Error & t-Statistic & Prob. \\
\hline \hline D(LNRGDP(-1)) & 0.437488 & 0.096066 & 4.554035 & 0.0002 \\
D(FDI) & $2.62 \mathrm{E}-11$ & $2.26 \mathrm{E}-11$ & 1.161598 & 0.2598 \\
D(PREM) & 0.000226 & $2.73 \mathrm{E}-05$ & 8.306190 & 0.0000 \\
D(RI) & 0.002391 & 0.000611 & 3.910762 & 0.0009 \\
D(RI(-1)) & -0.007993 & 0.001024 & -7.808011 & 0.0000 \\
D(RI(-2)) & -0.003631 & 0.000712 & -5.102695 & 0.0001 \\
D(LNGCF) & 0.159154 & 0.032433 & 4.907130 & 0.0001 \\
D(LNGCF(-1)) & -0.380966 & 0.062225 & -6.122378 & 0.0000 \\
D(LNGCF(-2)) & -0.214824 & 0.036065 & -5.956529 & 0.0000 \\
CointEq(-1)* & -0.584298 & 0.082597 & -14.00088 & 0.0000 \\
\hline \hline
\end{tabular}

* p-value incompatible with t-Bounds distribution.

Source: Authors own computation

In the short run model, the first lag difference of RGDP is statistically significant having pvalues of $0.02 \%$, which is less than 5\%. Allowing everything constant; when the short run coefficient of real gross domestic product could increase in one percent then economic growth increase by 43.7488 percent.

From the long run model, personal remittance has a positive effect on economic growth and its short run effect is also positive. From the above short run result of Auto Regressive Distributive lag (ARDL) model, personal remittance is significant having p-values of $1 \%$ percent, which is, much less than 5\% levels and have a positive coefficient. Other things remaining constant, it tells us that when personal remittance increases by $1 \%$ then economic growth increase by $0.0226 \%$.

The short run rate of inflation has positive and statistically significant affect economic growth. From most of the theory and general truth, rate of inflation affects economic growth negatively. Nevertheless, in the short, rate of inflation has a positive effect on economic growth. Assume other thing constant, $1 \%$ increase in inflation rate would account for 0.2391 percent increase in the economic growth of Ethiopia.

The Error Correction Term (ECT), which is estimated -0.584298 is negative as it was known and it is statistically significant. Thus, it indicates that $58.42 \%$ of the disequilibrium is adjusted before the next time period (year).

Generally, in the short run foreign direct investment, personal remittance, rate of inflation and gross capital formation have a positive coefficient. Results of Model Diagnostic Tests 


\subsection{Stability Test}

In order to check the goodness of the fitted ARDL model, the researcher used CUSUM tests of structural breaks for the long run equations. From the below Figure 1, there were no structural breaks as it was seen in the figure. Since the CUSUM test of the residual lies in between the two critical lines; therefore, the parameters are stable. Finally, since the blue line lies within the two red lines then the model ARDL was more stable.

Figure 1: Results of Stability Test

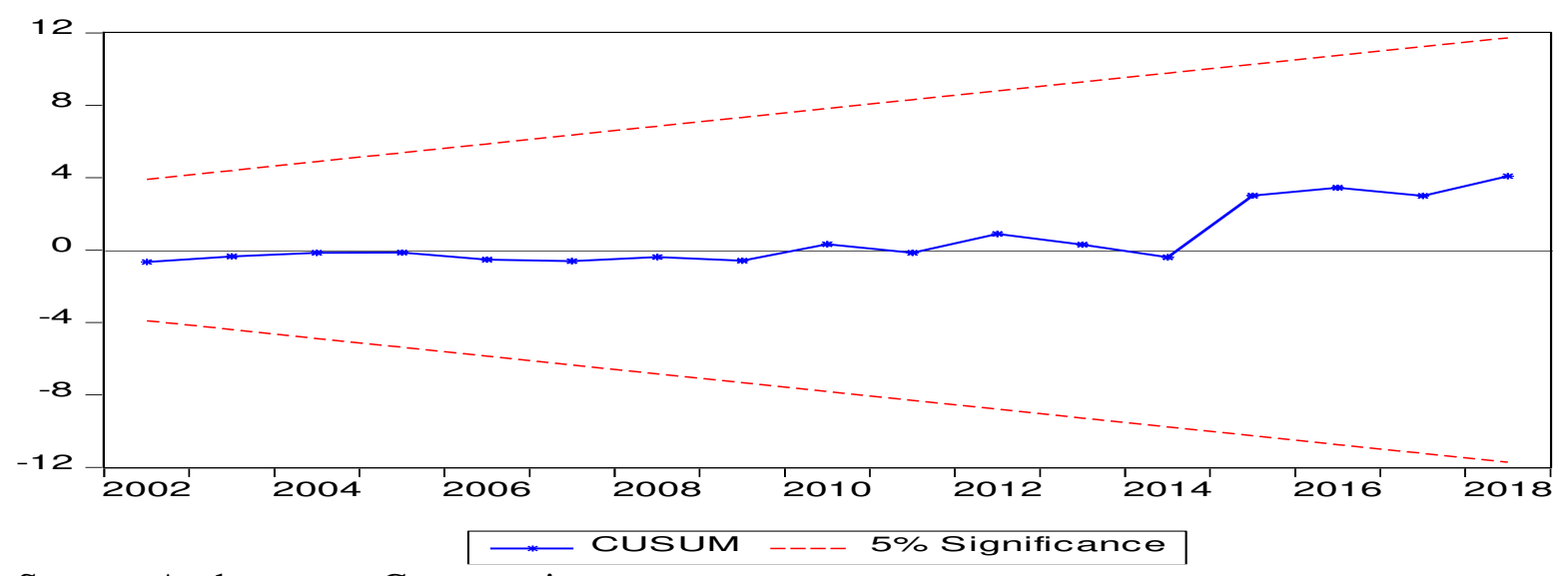

Source: Authors own Computation

\subsection{CONCLUSION AND RECOMMENDATION}

In this study, we investigated the effect of population number on economic growth of Ethiopia using an ARDL model approach from the period 1980 through 2019. From the result of ARDL model bound test result; the values of F-statistic (17.90609) value is greater than the upper boundary line (3.28) which indicates the existence of co-integration or long-run relationship between variables determined in this study.

From the result of the study, population growth has a positive effect on economic growth and statistically significant. This shows that an increase in population growth have an effect on the economic growth.

From the result of fitted long run ARDL model, population growth was statistically significant at $5 \%$ level having probability values of $0.01 \%$. A $1 \%$ increase in population number will result an increase in economic growth by 39.05 percent. In the long run, rate of inflation has a negative effect on economic growth. Moreover, the coefficient of error correction term is negative and statistically significant indicating any deviation from the long run equilibrium will adjusted by the speed of $58.42 \%$. 
Finally, the researchers recommended the concerned stakeholders that; the population number significantly affects the economic growth of the country; the government should plan a strategy, which will maintain the current positive effect of population size on economic growth of the country. In addition to that, by focusing on the activities, which are attractive for FDI that requires an encouraging environment and personal remittance, which have significance effect for economic growth on either solving shortage of foreign currency or as a means of capital for receivers.

\section{LIMITATION}

While conducting the study the researcher faced different obstacles such as lack of availability of adequate reference material, lack of adequate time, financial constraints and etc. The above reasons created difficulty and it was solved with a smooth operation.

\section{LIST OF ABBREVIATION}

$\begin{array}{lll}\text { ADF } & : & \text { Augmented Dickey Fuller } \\ \text { ARDL } & : & \text { Auto Regressive Distributed Lag } \\ \text { FDI } & : & \text { Foreign Direct Investment } \\ \text { GDP } & : & \text { Gross Domestic Product } \\ \text { GNP } & : \text { Gross National Product } \\ \text { HQ } & : \text { Hannan-Quinn information criterion } \\ \text { MOFED } & : \text { Ministry of Finance and Economic Development } \\ \text { MSc } & : \text { Masters of Science } \\ \text { POP } & : \text { Total population of a given country } \\ \text { POPGR } & : \text { Population Growth Rate } \\ \text { RI } & : \text { Rate of Inflation } \\ \text { SC } & : \text { Schwarz Information Criteria } \\ \text { VAR } & : \text { Vector Auto Regressive } \\ \text { VEC } & : \text { Vector Error Correction } \\ \text { VECM } & : \text { Vector Error Correction Model } \\ \text { WB } & : \text { World Bank } \\ \text { WDI } & : \text { World Development Indicator } \\ \text { PHD } & : \text { Doctor of Philosophy } \\ \text { I(0) } & : \text { Integration Order at level }\end{array}$


I(1) : Integration Order at first level

I(2) : Integration Order at second level

\section{DECLARATION}

I Mr Alemayehu Temesgen Befikadu hereby declare and affirm that the thesis entitled "An Empirical Analysis of the Effects of Population Growth on Economic Growth in Ethiopia using an Auto Regressive Distributive Lag (ARDL) Model Approach" is my work and that all sources of materials use for this research is appropriately acknowledged. I sincerely declare that this research is not submitted to any other institution anywhere for the award of any degree or diploma.

Correspondent Author: Alemayehu Temesgen Befikadu (MSc) Signature:

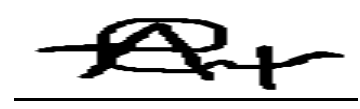

Berhanu Alemu Tafa (Ass. Prof, PHD)

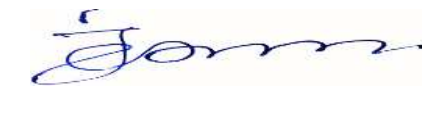

Signature
June 18, 2020

Date

Place: Wollega University, Nekemte

\section{Ethics Approval \& Consent of Participate}

The Authors declare that there are no competing interests associated with the manuscript.

\section{Availlability of Data and Material}

The author used data from the data base of Federal Reserve Bank of St. Louis (Link: https://fred.stlouisfed.org). Federal Reserve Bank of St. Louis allow research to use the data for solving to many problem of the world country.

\section{Funding}

The research didn't get any support or fund and it was done by the author himself.

\section{ACKNOWLEDGMENTS}

My special thanks go to Almighty God for giving me ability and patience to accomplish this piece of work. My deepest appreciation and special thanks go to my major advisor, Dr. Berhanu Alemu Tafa, for their invaluable and constructive comments on the manuscript of the research thesis development. 
Last but not least, let me take this opportunity to forward my thanks to my Mother Mulu Regasa Negeri, friends, staff workers, sources of my secondary data organizations and relatives who supporting a lot directly or indirectly in my work of this manuscript.

\section{Consent for Publication}

Alemayehu Temesgen Befikadu give my consent for information about myself to be published in BMC Research Note, with manuscript number: RESN-D-21-00553 and corresponding author: Alemayehu Temesgen Befikadu.

I understand that the information will be published without my/my child or ward's/my relative's (circle as appropriate) name attached, but that full anonymity cannot be guaranteed.

I understand that the text and any pictures or videos published in the article will be freely available on the internet and may be seen by the general public. The pictures, videos and text may also appear on other websites or in print, may be translated into other languages or used for commercial purposes.

I have been offered the opportunity to read the manuscript.

Signing this consent form does not remove my rights to privacy.

Name: Berhanu Alemu Tafa (Ass. Prof, PHD)

Date: April 26, 2021

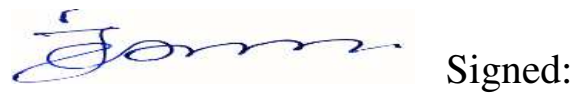

Author name: Alemayehu Temesgen Befikadu

Date: April 26, 2021

Signed:

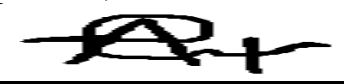

Please keep this consent form in the patient's case files. The manuscript reporting this patient's details should state that 'Written informed consent for publication of their clinical details and/or clinical images was obtained from the patient/parent/guardian/ relative of the patient. A copy of the consent form is available for review by the Editor of this journal.

\section{Competing interests}

Authors' interpretation of data or presentation of information may be influenced by the corresponding author. Author did not get financial competing interests and the paper was done without any fund. The publications are produced in a responsible and ethical manner. 


\section{Author's Contributions}

Alemayehu Temesgen Befikadu (corresponding authors) designed the hypothesis, wrote the theory, analyzed the experiment and the data contributed from World Bank data base. Assistance professor Berhanu Alemu Tafa (PHD) contributed as advisor.

\section{Authors Information}

\section{Name: Alemayehu Temesgen Befikadu (MSc) : Corresponding Author} alextame9@gmail.com,

Department of Economics, Ambo University,

Ambo, Ethiopia

Tell: +251911534723

2. Berhanu Alemu Tafa (Assistance Professor, PHD) : Corresponding Co-author berhanuje@gmail.com,

Department of Economics, Ambo University

Ambo, Ethiopia

Tell: +251913652478

\section{REFERENCE}

Akhilesh Ganti and Reviewed by Eric Estevez, (2020). Definition of Real Gross Domestic Product: updated Mar 7, 2021.

H.R.Anulawathie Menike, A Literature Review on Population Growth Economic Development International Journal of Humanities Social Sciences and Education 2018, 5(5): 67-74

Boserup, Ester. (1965). The Conditions of agricultural growth: The Economics of Agrarian Change under Population Pressure. New York: Aldine Pub. Co.,

Brown et al (1975). Techniques for testing the Constancy Regression Relationships over Time: Journal of the Royal Statistical Society. Series B (Methodological) Vol. 37(2), pp. 149 192, Retrieved March 15, 2021.

Bruce Felmingham, Natalie Jackson and Kate Weidmann. (2004). Population Neutralism: A Test for Australia and its Regions, School of Economics Discussion Paper 2004-02, Hobart, Tasmania 7001, Australia,: January 13th 2004. University of Tasmania, ISSN 1443-8593 ISBN 1862951705

Bucci, Alberto, 2008. "Population growth in a model of economic growth with human capital accumulation and horizontal R \& D," Journal of Macroeconomics, Elsevier, vol. 30(3), pages 1124-1147, September.

Eli H. Tartiyus, Mohammed Inuwa Dauda, and Amade Peter, (2015); Impact of Population Growth on Economic Growth in Nigeria, OSR Journal Of Humanities And Social Science (IOSR-JHSS), 20(4), PP115-123

Emeka Nkoro and Aham Kelvin Uko, 2016. "Autoregressive Distributed Lag (ARDL) cointegration technique: application and interpretation," Journal of Statistical and Econometric Methods, SCIENPRESS Ltd, vol. 5/4, pages 1-3. 
Gideon Kiguru Thuku, Gachanja Paul and Obere Almadi, The impact of population change on economic growth in Kenya: International journal of economics and management sciences, Vol. 2, No. 6, 2013, pp:44.

Gujarati Damodar N., (1997 and 2004), Basic Econometrics, $3^{\text {rd }}$ Edition, India, The Augmented Dickey-Fuller (ADF) Test, Testing the Significance of More Than One Coefficient. 2004.

Kassahun Alemu, June, 2014, Impact of Population Growth on the Ethiopian economic Performance, from Addis Abeba University

Malmberg, B., Tegenu, T. Population Pressure and Dynamics of household Livelihood in an Ethiopian Village: An Elaboration of the Boserup - Chayanavian Framework. Popul Environ 29, 39 - 67 (2007).

Minh Quang Dao, Population And Economic Growth In Developing Countries, international journal of academic research in business and the social sciences, January 2012, Vol. 2, No. 1, p:9.

Pesaran M. H, Shin Y. and Smith R.J. (2001) 'Bounds Testing Approaches to the Analysis of Level Relationships'. Journal of Applied Econometrics 16:289-326.

Peterson, E. Wesley F., (2017). "The Role of Population in Economic Growth" Faculty Publications: Agricultural Economics. 171.

Roger E. A. Farmer (1997), Macroeconomics, Department of Economics UCLA 405 Hilgard Avenue Los Angeles CA 90024 rfarmer@econ.ucla.edu September, 97

Shahjahan Ali, Khandaker Jahangir Alam, Shafiul Islam, Morshed Hossain. 2015. An Empirical Analysis of Population Growth on Economic Development: The Case Study of Bangladesh, International Journal of Economics, Finance and Management Sciences. Vol. 3, No. 3, pp. 252-259.

MALThuS, T., O’Flaherty, N., Valenze, D., Wrigley, E., Binmore, K., \& O'Brien, K. (2018). An Essay on the Principle of Population: The 1803 Edition (Stimson S., Ed.). New Haven; London: Yale University Press. doi:10.2307/j.ctv1bvnf95

Todaro, M. P., \& Smith, S. C. (2006). Economic Development. Boston: Pearson Addison Wesley.

Tomas Frejka, (1974). "The Future of Population Growth: Alternative Paths to Equilibrium, New York: John Wiley and Sons, Inc,. 1973 vix, 268 pp. Hardbound, \$9.95.

Richard Williams, Serial Correlation; Very Brief Overview, University of Notre Dame, https://www3.nd.edu/ rwilliam/, Last revised January 22, 2015. 